\title{
Analyzing personal embodied experiences: Autoethnography, feelings, and fieldwork
}

The International Journal for Translation \& Interpreting Research trans-int.org
Sari Hokkanen

University of Tampere, Finland

Sari.Hokkanen@staff.uta.fi

DOI: 10.12807/ti.109201.2017.a03

\begin{abstract}
The embodied, emotional experiences of the participant-researcher during fieldwork can yield useful information on the social setting influencing interpreting practices when analyzed as part of ethnographic research designs. This paper presents examples of methods for collecting and analyzing somatic and affective field experiences, occurring during the simultaneous interpreting of church services, as well as the insights gained from the analysis of such experiences. The discussion is based on my autoethnographic $\mathrm{PhD}$ research on simultaneous interpreting in church.
\end{abstract}

Keywords: embodiment, emotion, fieldwork, ethnography, autoethnography, research methods

\section{Introduction}

The idealistic image of scientific research entails strict adherence to objectivity and emotional neutrality, much like the idealistic image of interpreting (Bahadır, 2004, p. 807). This image has, however, been contested, both regarding practicing interpreters (Bahadır, 2004; Bontempo \& Malcolm, 2012) and interpreting and translation researchers (e.g. Bahadır, 2004; Baker, 2001; Koskinen, 2008). Indeed, insofar as interpreting and translation are regarded as social phenomena, the inevitable influence of the researcher as a social being on the research process becomes difficult to circumvent. The ethical benefits of reflecting and reporting on such influences are obvious and highly important; however, they remain outside the scope of the present discussion. In this paper, I focus on some of the methods with which we can examine our subjective, embodied experiences as researchers conducting fieldwork and the analytical benefits such examination may yield. More specifically, my discussion draws on traditions in anthropology and ethnography in that it focuses on participant-observer fieldwork. The paper is based on the autoethnographic study I conducted for my $\mathrm{PhD}$, examining simultaneous interpreting in church (Hokkanen, 2016). Thus, fieldwork in this paper is understood as a prolonged activity involving first-person experience, reflection, and writing in a setting where the researcher already has one or several social roles besides that of a researcher.

In the remainder of the paper, I first discuss theoretical and methodological grounds for analyzing embodied field experiences in interpreting research, after which I move on to presenting three examples of 
such experiences. In connection to the examples - feeling rushed, disgust, and joy - I explain the methods with which I 'translated' the embodied experiences into analyzable research material as well as the methods of analysis. A central tenet of my argument is that writing is treated, not solely as a means of reporting, but as "a method of discovery and analysis" (Richardson, 1994, p. 516). I will also highlight some of the findings gained from the analysis, even though the focus will remain on methodological issues. The paper concludes with a discussion on the limitations and possible benefits for Interpreting Studies of analyzing the researcher's embodied field experiences.

\section{Embodiment and feeling in autoethnographic fieldwork}

In this section, I present a theoretical and methodological background for the discussion on analyzing embodied field experiences. First, I define embodiment as it is used in this paper and discuss the social underpinnings of embodiment and feelings. Second, I introduce the methodology of autoethnography that was used in the study on which the paper draws.

\subsection{Embodiment, feeling, and the social world}

Social and anthropological studies have used the term embodiment in two main ways (Csordas, 1990; Niedenthal \& Barsalou, 2009). According to the first usage, embodiment refers to the body as an object, and it is examined from an outward perspective. This perspective is familiar to Interpreting Studies, as it can be taken to include kinetic factors such as the gestures and positioning of research participants that can be observed in live situations or on video (e.g. Poyatos, 1987/2002; Roy, 1996). By contrast, according to the second usage of the term embodiment, the body is not seen as an object but a subject. Thus, as an "existential ground of culture" (Csordas, 1990, p. 5), the body provides us with first-hand, visceral experience of the world, thus being "a necessary precondition for subjectivity, emotion, language, thought, and social interaction" (Niedenthal \& Barsalou, 2009, p. 140; see also Csordas, 1990). While this second meaning of embodiment may have had a less prominent position in Interpreting Studies, a similar understanding of the concept has been presented to Translation Studies by scholars such as Hanna Risku (e.g. 2010) in connection to Situated and Embodied Cognition and Douglas Robinson (e.g. 1991) in connection to the somatics of translation. In the present paper, I employ this second understanding and treat embodiment from the perspective of the experiencing agent, rather than that of a detached observer.

My discussion on embodiment mainly focuses on somatic and affective experiences, or feelings, which can be seen as constituents of emotion or affect (e.g. Shweder, 2004; Wetherell, 2012, Ch. 2) ${ }^{\text {i }}$ In addition to somatic and affective feelings, emotions can be seen to involve aspects such as environmental determinants, self-appraisal, social appraisal, and patterns of expression (Shweder, 2004, p. 92). Thus, in this paper, embodiment is treated as one aspect of emotion, and the discussion foregrounds subjective somatic

\footnotetext{
${ }^{\mathrm{i}}$ In addition, feelings have been defined and their relationship to emotions has been conceptualized in a variety of ways in different disciplines; see Niedenthal et al. (2005) or Wetherell (2012, Ch. 2) for a fuller discussion.
} 
and affective experiences, even though these are seen as closely intertwined and interacting with other, cognitive and social processes. Indeed, recent developments in cognitive sciences suggest that embodiment is involved, not only in our emotions, but in all our cognitive processes (Niedenthal \& Barsalou, 2009; Niedenthal et. al, 2005; see also Risku, 2010). In other words, knowledge is largely constituted by "stored embodiments," so that simply "thinking about an object produces embodied states as if the object were actually there" (Niedenthal et. al, 2005, p. 187). What distinguishes emotions from other types of embodied cognition is the highly personal significance of the stimulus giving rise to a bodily reaction (e.g. Rosaldo, 1984).

In this paper, embodiment and feelings are examined mainly from a sociological perspective. In light of traditional Western thinking, this may seem a counterintuitive choice, since experiences involving our emotions are often taken as highly personal, intrapsychic phenomena. Moreover, a choice to study such experiences with a first-person approach may cast further doubt on the potential sociological contribution of the discussion. However, there is a large body of research highlighting both social and individual dimensions of emotion (e.g. Lutz \& White, 1986). For instance, according to psychologist Jerome Bruner (1990, p. 59), embodied experiences are closely related to social identities and the ways of being and feeling we have acquired as a part of socialization processes. For these reasons, we have argued elsewhere (Hokkanen \& Koskinen, 2016) that affectivity can provide a useful point of entry for studying the interface between an individual and the social world within Translation and Interpreting Studies.

\subsection{Autoethnography and the embodied nature of fieldwork}

Autoethnography builds upon the ethnographic tradition; however, in contrast to conventional ethnography, autoethnography places more emphasis on using the personal experiences of the researcher-participant to understand facets of the social world within which s/he is embedded (e.g. Ellis \& Bochner, 2000; see also Napier, 2011). Thus, while reflexivity - in the sense of thinking through the implications of the researcher's person on the study - is important in all qualitative research designs (Tracy, 2010; see also Baker, 2001), in autoethnography, the interaction between the researcher's multiple identities as a researcher and as a member of a social world constitutes a major part of the 'observations' that are then analyzed. Autoethnographic research designs incorporate the researcher's experience of a social world into the research materials in varying degrees (Ellis \& Bochner, 2000). However, in accordance with the ethnographic tradition, the amount and variety of research materials in autoethnography is not necessarily predetermined prior to fieldwork (cf. Hammersley \& Atkinson, 1995). Rather, the aim is to collect a broad range of data (Willis, 2000), such as documents, audio and video recordings, photographs, and cultural artefacts.

Nevertheless, the quintessential source of research material in both ethnography and autoethnography is fieldwork and the notes generated through this prolonged presence of the researcher in a social world (Sanjek, 1990). Ethnographic fieldwork has been described as a practice that "privileges the body as a site of knowing" (Conquergood, 1991, p. 180). The process of taking fieldnotes, then, involves the 'translation' of embodied sense into language (Willis, 2000, p. xii). It is important to keep in mind, however, that especially in an autoethnographic research design, potentially including the entire life-history of the researcher, such 'translation' can never be complete; it is impossible to record all the traces that a culture can leave on the body and person of the researcher comprehensively in an initial field 
journal, which could then be analyzed from an 'objective' perspective (see Spry, 2001).

The methods of analysis employed in an autoethnographic study usually combine two elements: introspection and cultural analysis. These elements have been described in terms of zooming in to personal, embodied experiences and zooming out to wider cultural concepts and frameworks (Chang, 2008: p. 129; Ellis \& Bochner, 2000; see also Bahadır, 2004, p. 807). Introspection and cultural analysis of this kind are not single steps in a linear process of analysis, but practices that are carried out iteratively. Indeed, the process of ethnographic analysis is far from linear. An illustrative expression used by Willis (2000, p. xi) in connection to ethnographic analysis is that "you throw concepts at things," the "things" referring to research materials and observations made in the field. In other words, ethnographic analysis is characterized by experimentation and creativity that aims "to deliver analytic and illuminating points not wholly derivable from the field but vital to conceptualizing its relationships" (Willis, 2000, p. xi).

The autoethnographic study that I conducted for my $\mathrm{PhD}$ examined simultaneous interpreting in church (Hokkanen, 2016). The study focused on the interplay of social meanings and personal experiences of volunteer interpreting in a religious setting, more specifically, in two Pentecostal churches in Finland. I examined the social meanings related to service and religious experience that were attached to the volunteer, Finnish-to-English interpreting of weekly church services. This examination of social meanings was combined with a scrutiny of how they were reflected on my personal, embodied experience of church interpreting. My research data consisted of field journals that I kept during fieldwork in the two churches (in the winter of 2009-2010 in Tampere, and from 2011 to 2014 in Seinäjoki) as well as of a document produced for a church course ${ }^{\mathrm{ii}}$, a church website presenting types of volunteer work the church offered, portions of my personal journals written prior to the study ${ }^{\mathrm{iii}}$, and audio and video recordings of my church interpreting.

My practices of taking fieldnotes evolved throughout the research process (see Hokkanen, 2016), but I eventually found most fruitful a combination of a small notebook for hand-written notes and a field journal proper in an electronic format. Thus, I had the notebook in the interpreting booth for quick notes and immediate impressions, which I then completed into a fuller narrative on a word processor, usually a day or two later. I analyzed the field journal by going through a printed copy of it several times, making notes, coding, and using different colors to underline and circle portions of the text.

I had been involved in the two churches and their interpreting practices for several years prior to the study as a member and volunteer interpreter, but for the purposes of the study, I also dedicated time for conducting fieldwork in the two churches: in the first, the Tampere Pentecostal Church, I returned to the 'field' after having moved elsewhere a few months earlier, while in the second, the Pentecostal Church of Seinäjoki, the fieldwork was intertwined with my regular church life. Thus, especially throughout the fieldwork in Seinäjoki, I had to negotiate between several different identities and scrutinize

\footnotetext{
ii This course included teachings and discussions on what the church deemed as 'the basics' of Christian living.

iii The personal journals were written between 2001 and 2014. Their use in the doctoral study was limited to a comparison between narratives about personal religious experiences I had written without a research orientation and those I had recorded in the field journal.
} 
their influence on the observations and interpretations I made; while in the 'field,' I was not only a researcher of interpreting, but also a church member and believer, a wife and an (at times, tired and overwhelmed) mother, a professionally-trained freelance translator and interpreter, and, towards the end of the research process, also an instructor of interpreting and translation at the University of Tampere. In the remainder of this paper, I will illustrate how some of these identities came to influence my field experiences.

\section{Three examples of analyzing embodied field experiences}

In this section, my aim is to present possible ways of processing, analyzing, and understanding the researcher's somatic and affective experiences in an autoethnographic research design. The following discussion covers three examples of embodied experiences that I had during fieldwork: feeling rushed, disgust, and joy. In each example, my aim is to discuss processes of data collection and analysis as well as the insights that the analysis provided into interpreting in the church, creating a 'thick description' of the practice, and into the complex relationship between the researcher's multiple social selves: in my case, as a researcher, a church member, and a professionally-trained interpreter (cf. Bahadır, 2004).

\subsection{Rushed}

In the field journal I kept while interpreting in the Seinäjoki church (from 2011 to 2014), most entries begin with a comment on feeling rushed due to arriving at the church only ten or five minutes before the service would begin, or, somewhat more rarely, with a comment on having plenty of time to prepare myself and the booth for interpreting. ${ }^{\text {iv }}$ At first glance, such comments may seem decidedly mundane and, perhaps, irrelevant for the purposes of the study (for who, in our hectic societies, does not feel pressured by an apparent lack of time?). Furthermore, it would be easy for me to dismiss these comments as a personal idiosyncrasy, since I detest being late. Indeed, for this reason I did not pay much attention to them until later in the research process. However, a closer scrutiny of this embodied experience shed light on important social meanings that subtly influence the ways in which simultaneous interpreting is understood and practiced in the church. Before focusing on the insights gained from the analysis, however, I will first describe the methods with which the embodied experiences were translated into research data and analyzed.

The experience of feeling rushed, while unpleasant and anxiety-inducing, is by no means uncommon in my daily life, and I would not have remained aware of it in relation to specific interpreting instances had I not meticulously recorded such experiences in my field journal. The process of analyzing the experience began from reading and coding the field journal, but only produced results after a long process of "throwing concepts" at the experience (Willis, 2000, p. xi). For feeling rushed, I used the code kiire (Finnish for being rushed or in a hurry). However, apart from noticing the frequency of the relevant code, I did not, at first, find this experience as significant and interesting as some other recurring themes. Rather, only later in the research process was I able to connect this embodied experience to cultural topics that I had come to

\footnotetext{
iv It was the custom for interpreters to prepare the booth and to provide the receiverheadsets to the listeners, even while interpreting.
} 
identify as relevant in the study up to that point. This was several years after making the initial observation on the frequency of the experience.

My anxiety over feeling rushed as well as comments on the occasional lack thereof when coming to interpret at church can be seen as a response to the social meanings attached to preparation before serving in church and to preparation in professional interpreting. When I re-examined the instances of feeling rushed, I realized that I was never actually late. What had caused the anxiety was, rather, a fear of not having prepared enough. Traditionally, in Pentecostal church life, there has been a complex tension between the unavoidability of preparation and planning, on the one hand, and a desire to allow room for the Holy Spirit to 'move freely' in church gatherings, on the other (Kärkkäinen, 2001). Thus, while Pentecostals often find it necessary to prepare for serving in the church, they also value spontaneity, evidenced by a lack of formal liturgy in the church, for example. Furthermore, deviations from the often loosely-planned proceeding of the church service are common, since they are interpreted as having been prompted by the Holy Spirit. For interpreting, this means an unavailability of preparatory materials such as the preacher's notes on the sermon - since many sermons are finalized at the last minute - and a seemingly widely-spread custom among the interpreters in the two churches I studied of not preparing in any way for interpreting. However, because my background is in professional interpreting, I have sometimes felt uneasy about this attitude, in myself and in others.

To summarize, my feeling rushed when coming to interpret in church has roots in the tensions between the social meanings prevalent in the church and those typical of professional interpreting and between my identities as a church member and a professionally-trained interpreter: As a servant of God, I am expected to surrender myself, my talents, and the results of my interpreting to Him. At the same time, however, as a trained interpreter, I am expected to take my work (even if voluntary) seriously by always preparing for an interpreting assignment. Thus, an anxiety over feeling rushed, typical to my daily life as it may be, can also be fruitfully analyzed in tandem with cultural analysis, allowing for the multiple pulls of the researcher's different social identities to paint a more nuanced portrait of the object of study.

\subsection{Disgust}

In contrast to the recurring and even mundane feeling of being rushed, discussed above, my second example of an embodied field experience occurred only once and with a force that compelled me to analyze it without delay. The experience was a strong feeling of disgust directed at the unassuming, A6-sized gray notebook that I used for taking fieldnotes in the interpreting booth at church. This experience occurred in May, 2012, some six months after I had begun to take notes of my own interpreting, and it indicated for me a conflict between my identities as a researcher and a church member. The event was a regular Sunday service. I had all my usual interpreting aids (water, mints, and my smart phone including a Bible app that I used for locating Scripture references) and research equipment (the gray notebook and a pencil) on the booth table, and I had taken very few lackluster notes, mainly commenting on the structure of the service. Towards the end of the service, I glanced down at the notebook, opened and eagerly waiting on the table, when I was overcome by a feeling of disgust and even physical nausea. As a statement, I angrily pushed the notebook aside for the rest of the service.

My main method of analyzing this embodied experience was writing about it at different times, in different genres, and for different audiences. Even though I had not taken notes on the feeling of disgust in the booth, its 
intensity led me to return to it both in my field journal proper and later in the process of writing research reports. Three days after the service I wrote in my field journal the following comments:

I felt disgusted over having to write in the notebook. It's actually absurd that I haven't paid attention to this before, but I've always thought (and I know people in the church think) that I can't encounter God as deeply as I could if I focus on something other than Him. Even though I try to observe the religious experience during the experience, and not think about something completely irrelevant, I feel I'm taking on a researcher role, extra baggage. It distracts me. I'm no longer there as a child of God, in order to encounter Him, but as an observer. (Field journal entry, 31 May, 2012)

In other words, I was troubled by the nature of participant-observation and felt that trying to observe my spiritual life ended up distorting it. Moreover, I felt troubled about the risk of sacrificing personally meaningful spiritual experiences by trying to exploit them for the purposes of research. However, as the research progressed, I became more accustomed to negotiating between my spiritual and research identities. Much of this development took place some three years later to the instance itself, as I processed the feeling of disgust about my notebook into a poem ${ }^{\mathrm{vi}}$ for a research paper and contrasted it with a short narrative based on a later field experience in a discussion about developing a tolerance for the inherent ambiguity in being simultaneously a participant and an observer of one's participation.

Thus, what I had experienced as a strong, bodily sensation of disgust while in the field, I interpreted first as a signal of a personal spiritual conflict, but later as a response to the ambiguity in (auto)ethnographic fieldwork. I came to realize that deep feelings of uneasiness with potentially exploiting others' or one's own life for research purposes is inherent in both ethnography (Behar, 1996; see also Bahadır, 2004; Koskinen, 2008) and autoethnography (Doloriert \& Sambrook, 2009), which, again, highlights the need for selfreflexivity and ethical judgment (see Hokkanen, 2016, Ch. 5). Nevertheless, the feeling of disgust also highlighted certain social meanings in the church: my initial interpretation of the experience was rooted in an internalized, nonnegotiable set of priorities, according to which a personal encounter with God in church services should come first despite what duties I might have there, be it interpreting or doing research.

\subsection{Joy}

The third example of an embodied field experience that I analyzed over the course of my PhD research is that of overflowing joy taking place when I interpreted the post-sermon prayer led by the preacher in a Wednesday evening service. This experience, within the conceptual framework provided by the church, would be understood as a religious experience (see Hokkanen, 2016; also e.g. Nelson, 2005). I selected this experience as an example in order to illustrate a process of analysis that does not begin with the writing and reading of fieldnotes. Even though I focus on a single occasion here, the experience itself was not new to me. However, while the field experience was familiar, the experience of analyzing it differed from the ordinary and

\footnotetext{
${ }^{\mathrm{v}}$ My translation of the original Finnish entry.

vi Such mixing of genres in academic papers is typical of certain strands of autoethnography (see e.g. Ellis \& Bochner, 2000).
} 
highlighted, for me, the embodied aspects of not only fieldwork but also the work of analyzing personal experiences.

Unlike the two examples discussed above, I did not record this experience of joy initially in my notebook in the booth; rather, it occurred on an occasion when I recorded my own interpreting into an audio file with my smart phone for the first time. This occasion took place in January, 2014, and I continued to make recordings intermittently during my interpreting shifts for an additional seven months. Importantly, the aim of the recordings was to function as a fieldnote in a modality other than written text, and not as a basis for detailed transcription and textual analysis. While such analysis might have proven fruitful, I decided to exclude it from the research design for practical reasons and in order to focus on the cultural analysis of experience, not that of speech.

The process of analyzing the experience of joy began from listening to the recording, after which I wrote initial analytical and reflective comments in my field journal. Some three months later, I wrote a narrative about the experience of listening to the recording for an article draft. I eventually omitted the narrative from the final paper, however. The process of writing about the experience for a different audience and in a different genre (in this case, creative nonfiction embedded in an academic paper), again, did not aim at reporting the results of analysis, but, rather, at thinking about and analyzing the research material through writing (see Richardson, 1994). In the process of drafting, I re-listened to the audio recording several times. Below is the narrative in its final form.

I'm not sure I will use this, I think as I put on my headphones and hit play on my smart phone recorder. I wince as I listen: they're talking about a girl - not a he! Oh, and there's a sentence left hanging mid-air. It's been a while since I've last listened to myself in English (are those voiced s's voiced enough?). This Wednesday meeting was the first time I recorded my interpreting, and I'm trying to find the best way to analyze it in my research. I continue to listen, at the same time a bit embarrassed about the mistakes I hear myself making and slightly annoyed by the fact that I can't help but listen to those mistakes. After all, my point was never to evaluate the quality of my (or any other church interpreter's) interpreting output. It's proved difficult to weed out that vintageinterpreting-research-influenced predisposition to start mentally categorize mistakes whenever listening to recorded interpreting.

Soon, almost in spite of myself, I forget the confused personal pronouns, and my attention is grabbed by the final moments of the sermon when the preacher begins to pray in a fervent tone. As I listen to my English rendering of that prayer and the distant echo of the preacher's voice as it rises and falls and penetrates the less-than-soundproof walls of the interpreting booth, my body and spirit remembers what it felt like. The excitement, the bubbling joy, my voice on the verge of giggling and tears. The child-like enthusiastic expectancy - the certainty - that God is pouring out His love and forgiveness and healing over souls and bodies. Seeing the young woman who listens to my interpreting tremble from tears and lift up her hands in worship. Is this only a memory, or is that prayer anointed by the Holy Spirit, or why can I hardly sit still? Why am I giddy and teary-eyed again, listening to the recording two days later?

And three months later, writing this?

The purpose of the narrative is to reflect and evoke emotions related to the experience, and it functions as a means of both analysis and reporting. As we have argued elsewhere (Hokkanen \& Koskinen, 2016), narrative can be 
taken as a useful tool in studies on affectivity, since narratives are the primary way in which humans make sense of personally relevant experiences (Polkinghorne, 1988).

The experience of joy - both in the booth and when listening to the recording and writing about it - connects my identities as a church member, interpreter, and researcher, each identity being intertwined with understandings and assumptions prevalent in their respective social worlds. First, when taken as a religious experience, the feeling of joy while rendering a prayer is founded upon the cultural beliefs and assumptions that I have internalized as a church member (Nelson, 2005). One such belief has to do with the expectation of believers 'encountering God' through the Holy Spirit in services, often in tangible ways so that people's minds, bodies, and emotions may be affected (or 'touched by God'). Second, my identity as an interpreter and the task of interpreting were also integral to the experience. I felt that by giving an English rendering of the preacher's fervent prayer allowed me, in a sense, to participate in his experience of God or, at the least, his affective feeling at that moment. Indeed, it has been suggested that the fact that interpreters relay others' accounts in the first person allows them to coexperience these accounts, which may even lead to an elevated risk for vicarious trauma in certain healthcare settings (Bontempo \& Malcolm, 2012). Finally, the experience of joy was also connected to my identity as a researcher, since I relived the emotion during analysis. When listening to the recording, I was at my office on a regular workday, sorting and analyzing research materials. While the force of the relived emotion effectively blurred the boundaries between my identities as a believer and researcher, it also provided new research materials and raised new questions on the role of the body in fieldwork, which eventually have led to the views on embodiment I have presented here.

\section{Discussion}

The purpose of this paper was to indicate the analytical benefits to be gained from taking the researcher-participant's own somatic and affective field experiences under scrutiny. Specifically, I have argued that when researchers have several social roles in the setting they study, a focus on embodiment and feelings helps in tapping into this complex network of involvement. After all, emotions arise within us when something becomes personally relevant. Yet, the analysis of subjective feelings may also reveal important cultural assumptions and tacit understandings that affect interpreting practices in different social settings.

The three examples analyzed above also point to possible methods for the collection and analysis of emotional experiences. The discussion centered in the processing of fieldnotes, in writing about the experiences from different perspectives and in different genres that each provide new constraints and possibilities for expression and understanding, as well as in using recordings of interpreting as a stimulus for reliving the emotions having occurred during interpreting. Clearly, this is a limited array of the possible methods that could be employed in analyzing embodied field experiences, and they arise from the practical experiences I had in my $\mathrm{PhD}$ research. I would surmise that also other practices involving narrativity or performativity would be suited for the processing of emotions and embodied experiences in the field (see e.g. Spry, 2001). 
There are certain limitations to the incorporation of researchers' somatic and affective experiences into studies of interpreting that are useful to bear in mind. First, not all feelings we have as researchers during fieldwork may be analytically useful (cf. Delamont, 2009). Some have nothing to do with our research but with other aspects of our lives, and while their analysis may be useful for personal development, they may not provide relevant information about our object of study. Second, and perhaps less obviously, it is important to note that our memories of highly emotional experiences and events are not necessarily accurate, even though we sometimes feel that every detail and even the visual appearance of the situation are forever ingrained in our memory (Levine \& Pizarro, 2004). This is not to say that emotional memories were especially untrustworthy, simply that emotional memories are not more or less accurate than memories in general. Therefore, taking notes about their feelings and emotions is an important practice for researchers engaged in fieldwork because it will support their memory in later stages of research.

While ethnography seems to have gained a level of familiarity among scholars of translation and interpreting (e.g. Flynn, 2010; Hale \& Napier, 2013), to my knowledge, the centrality of embodiment in ethnographic research seems not to have been discussed previously in our discipline. Such discussion would be beneficial for the methodological development of our field, given that the embodied researcher him/herself, after all, is the main research instrument in ethnography (Conquergood, 1991, p. 180). The implications of the embodied interpreting researcher being the research instrument, beyond the analysis of somatic and affective experiences as discussed here, remain to be explored.

\section{References}

Bahadır, Ş. (2004). Moving in-between: The interpreter as ethnographer and the interpreting-researcher as anthropologist. Meta, 49(4), 805-821.

Behar, R. (1996). The vulnerable observer: Anthropology that breaks your heart. Boston: Beacon Press.

Baker, M. (2001). The pragmatics of cross-cultural contact and some false dichotomies in translation studies. In M. Olohan (Ed.), CTIS Occasional Papers, Vol. 1 (pp. 7-20). Manchester: Centre for Translation and Intercultural Studies, UMIST.

Bontempo, K., \& Malcolm, K. (2012). An ounce of prevention is worth a pound of cure: Educating interpreters about the risk of vicarious trauma in healthcare settings. In L. Swabey \& K. Malcolm (Eds.), In our hands: Educating healthcare interpreters (pp. 105-130). Washington, D.C.: Gallaudet University Press.

Bruner, J. (1990). Acts of meaning. Cambridge \& London: Harvard University Press.

Chang, H. (2008). Autoethnography as method. Walnut Creek, CA: Left Coast Press.

Conquergood, D. (1991). Rethinking ethnography: Towards a critical cultural politics. Communication Monographs 58, 179-194.

Csordas, T. J. (1990). Embodiment as a paradigm for anthropology. Ethos, 18(1), 547.

Delamont, S. (2009). The only honest thing: Autoethnography, reflexivity and small crises in fieldwork. Ethnography and Education, 4(1), 51-63.

Doloriert, C., \& Sambrook, S. (2009). Ethical confessions of the 'I' of autoethnography: The student's dilemma. Qualitative Research in Organizations and Management: An International Journal, 4(1), 27-45.

Ellis, C., \& Bochner, A. P. (2000). Autoethnography, personal narrative, reflexivity. Researcher as subject. In N. K. Denzin \& Y. S. Lincoln (Eds.), Handbook of qualitative research $\left(2^{\text {nd }}\right.$ ed., pp. 733-768). Thousand Oaks, London \& New Delhi: Sage. 
Flynn, P. (2010). Ethnographic approaches. In Y. Gambier \& L. van Doorslaer (Eds.), Handbook of Translation Studies (Vol. 1, pp. 116-119). Amsterdam: John Benjamins.

Hale, S., \& Napier, J. (2013). Research methods in interpreting: A practical resource. London, New Delhi, New York and Sydney: Bloomsbury.

Hammersley, M., \& Atkinson, P. (1995). Ethnography: Principles in practice (2nd ed.). London \& New York: Routledge.

Hokkanen, S. (2016). To serve and to experience: An autoethnographic study of simultaneous church interpreting. (Doctoral dissertation). University of Tampere. Retrieved from http://urn.fi/URN:ISBN:978-952-03-0232-0.

Hokkanen, S., \& Koskinen, K. (2016). Affect as a hinge: The translator's experiencing self as a sociocognitive interface. Translation Spaces, 5(1), 78-96.

Koskinen, K. (2008). Translating institutions. An ethnographic study of EU translation. Manchester, UK \& Kinderbrook, NY: St. Jerome.

Kärkkäinen, V.-M. (2001). Church as Charismatic fellowship: Ecclesiological reflections from the Pentecostal-Roman Catholic dialogue. Journal of Pentecostal Theology, 18, 100-121.

Levine, L. J., \& Pizarro, D. A. (2004). Emotion and memory research: A grumpy overview. Social Cognition, 22(5), 530-554.

Lutz, C., \& White, G. M. (1986). The anthropology of emotions. Annual Review of Anthropology, 15, 405-436.

Napier, J. (2011). If a tree falls in the forest, does it make a noise? The merits of publishing interpreting research. In B. Nichodemus \& L. Swabey (Eds.), Advances in interpreting research: Inquiry in action (pp. 121-152). Philadelphia: John Benjamins.

Nelson, T. J. (2005). Every time I feel the Spirit: Religious experience, ritual, and emotion in an African American church. New York University Press.

Niedenthal, P. M., Barsalou, L. W., Winkielman, P., Krauth-Gruber, S., \& Ric, F. (2005) Embodiment in attitudes, social perception, and emotion. Personality and Social Psychology Review, 9(3), 184-211.

Niedenthal, P. M., \& Barsalou, L. W. (2009). Embodiment. In D. Sander \& K. R. Scherer (Eds.), The Oxford companion to emotion and the affective sciences (p. 140). Oxford University Press.

Polkinghorne, D. 1988. Narrative knowing and the human sciences. Albany, NY: State University of New York Press.

Poyatos, F. (1987/2002). Nonverbal communication in simultaneous and consecutive interpretation. A theoretical model and new perspectives. In F. Pöchhacker \& M. Shlesinger (Eds.), The interpreting studies reader (pp. 235-246). London \& New York: Routledge.

Richardson, L. (1994). Writing: A method of inquiry. In N. K. Denzin \& Y. S. Lincoln (Eds.), Handbook of Qualitative Research (pp. 516-529). Thousand Oaks, London \& New Delhi: Sage.

Risku, H. (2010). A cognitive scientific view on technical communication and translation: Do embodiment and situatedness really make a difference? Target, 22(1), 94-111.

Robinson, D. (1991). The translator's turn. Baltimore \& London: The Johns Hopkins University Press.

Rosaldo, M. Z. (1984). Toward an anthropology of self and feeling. In R. A. Shweder \& R. A. LeVine (Eds.), Culture theory: Essays on mind, self, and emotion (pp. 135-157). Cambridge, London, New York, New Rochelle, Melbourne \& Sydney: Cambridge University Press.

Roy, C. (1996). An interactional sociolinguistic analysis of turn-taking in an interpreted event. Interpreting, 1(1), 39-67.

Sanjek R. (Ed.) (1990). Fieldnotes: The makings of anthropology. Ithaca, NY \& London: Cornell University.

Shweder, R. A. (2004). Deconstructing the emotions for the sake of comparative research. In A. S. R. Manstead, N. Frijda, \& A. Fischer (Eds.), Feelings and emotions. The Amsterdam symposium (pp. 81-97). Cambridge, New York, Port Melbourne, Madrid \& Cape Town: Cambridge University Press. 
Spry, T. (2001). Performing autoethnography: An embodied methodological praxis. Qualitative Inquiry, 7, 706-732.

Tracy, S. J. (2010). Qualitative quality: Eight 'big-tent' criteria for excellent qualitative research. Qualitative Inquiry, 16(10), 837-885.

Wetherell, M. (2012). Affect and emotion: A new social science understanding. London, Thousand Oaks \& New Delhi: Sage.

Willis, P. (2000). The ethnographic imagination. Cambridge \& Malden: Polity. 